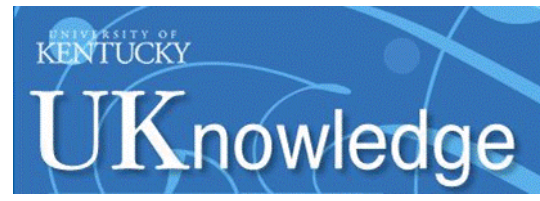

University of Kentucky

UKnowledge

August 2000

\title{
A Brazilian Challenge to Lewis's Explanation of Cult Mediumship
}

James M. Donovan

james.donovan@uky.edu

Follow this and additional works at: https://uknowledge.uky.edu/law_facpub

Part of the Anthropology Commons

Right click to open a feedback form in a new tab to let us know how this document benefits you.

\section{Repository Citation}

Donovan, James M., "A Brazilian Challenge to Lewis's Explanation of Cult Mediumship" (2000). Law Faculty Scholarly Articles. 437.

https://uknowledge.uky.edu/law_facpub/437

This Article is brought to you for free and open access by the Law Faculty Publications at UKnowledge. It has been accepted for inclusion in Law Faculty Scholarly Articles by an authorized administrator of UKnowledge. For more information, please contact UKnowledge@lsv.uky.edu. 
A Brazilian Challenge to Lewis's Explanation of Cult Mediumship

This article is available at UKnowledge: https://uknowledge.uky.edu/law_facpub/437 


\section{A Brazilian Challenge to Lewis's Explanation of Cult Mediumship}

\section{JAMES M. DONOVAN}

ABSTRACT Recruitment into peripheral possession trance cults has been explained as attempts to compensate for socio-economic deprivation and jural impotence. This model, best developed by I. M. Lewis, is reviewed and its predictions are tested against two types of Brazilian data. Firstly, national census figures of religious affiliation are compared with measures of socio-economic stress for a diachronic analysis. A second, synchronic analysis involves 62 respondents in Rio de Janeiro who completed questionnaires on socio-economic status, cultic affiliation, and perceptions of stress and gender inequality. The results offer only weak support for Lewis's original model, which may therefore profit from supplementation from other theoretical perspectives.

\section{Introduction}

Peripheral possession trance cults are those which, however prominent their cultural profile, play "no direct part in upholding the moral code of the[ir] societies" (Lewis, 1989: 27). Typical among such cults are the New World progeny of African religious systems, such as Haitian Voudon, Cuban Santaria, and Brazilian Candomblé.

To be a member of most of these cults is tantamount to being, or being in the process of becoming, a spirit medium. 'Medium' is a contested category and can refer to one who is "chronically possessed" (Lewis, 1986: 25), where being 'possessed' means having one's personality substituted for that of another. Rouget (1985) offers a more complex set of criteria: mediumship belongs to a subset of trance (as opposed to ecstasy), distinguished by the type of man/spirit relationship which leads to divination. For Rouget, possession is only one kind of mediumship. For the purpose of this discussion, I shall read 'medium' as a person who permits a spirit to assume control of her/his body and mind for the purpose of communicating with others.

A recurring question in the sociology of religion is: who becomes a medium in the peripheral possession trance cults? One influential response has been that persons are drawn toward cult mediumship as a reaction to political powerlessness and socio-economic marginality. Such people use the cult to compensate for these deficits.

This perspective has been subjected to sufficient scrutiny to establish its general validity (e.g. Pereira de Queiroz, 1989; Lerch, 1980; 1982). The question therefore is not whether the model is accurate, but whether it is complete. Does it reveal gaps or limits which might benefit from supplementation by other perspectives? I shall pursue this query by challenging the most influential 
articulation of this view, I. M. Lewis's classic Ecstatic Religion: A Study of Shamanism and Spirit Possession (1971).

\section{Sociological Correlates of Spirit Mediumship}

\section{Lewis's Sociology of Spirit Possession}

Lewis initially posed this question: "Is possession an entirely arbitrary and idiosyncratic affair; or are there particular social categories of person more or less likely to be possessed?" (Lewis, 1989: 23). Despite the way in which the question is phrased, these alternatives do not exhaust all possibilities. The fact that mediumship fails to follow social grooves does not entail that it must be arbitrary or idiosyncratic. However, we see from Lewis's framing of the question where he will end up: possession cults, frequented overwhelmingly by women, are "thinly disguised protest movements directed against the dominant sex" (Lewis, 1989: 26). Lewis points out that "those whose lives flow smoothly without much difficulty or distress are rarely summoned by the spirits". Instead, "the devotee is prone to experience possession in difficult, stressful situations, from which there is otherwise no satisfactory escape" (Lewis, 1989: 60).

Membership in such cults allows participants to extort material goods and psychological stroking from culture mates, usually family members who are often the agents of the oppression of the afflicted, either personally or representatively (cf. Bourguignon, 1991: 23; Lewis, 1986: 39). Lewis highlights the fact that most mediums are married women and characterizes possession states as one weapon in the war between the sexes. This tableau is but a special instance of the general principle that long-term involvement in "dramatic rituals offer these otherwise underprivileged persons some degree of emancipation from frustrating traditional confinements" (Lewis, 1989: 91).

This underscoring of social marginality explains the involvement of "underprivileged persons" other than married women, such as ex-slaves and the servile classes (Lewis, 1989: 92), religious minorities seeking supernatural confirmation of their extremist tenets (Bilu \& Goodman, 1997), and in the case of Brazilian Candomblé, male homosexuals (Leão Teixeira, 1986: 42; Lerch, 1982: 238; Mischel \& Mischel, 1958: 256).

Several writers have used Lewis's model to understand their own ethnographic data better. For example, Pereira de Queiroz (1989: 100-101) does not doubt that the attraction of Umbanda, another Brazilian spiritist cult, is its instrumental value, whether for the lower strata to ascend the social scale or for the higher classes to maintain their positions.

Fieldwork in Brazil by Patricia Lerch (1980; 1982) revealed similar results. She attributes Umbanda's skewed sex ratio to its offering "access to 'power' ... [thus offsetting] the relative powerlessness typical of comparable socioeconomic roles available to [women] in the modern society" (Lerch, 1982: 237). Increased power, in turn, rests on the medium's expanded information network and the prestige and power attributed to superior religious knowledge (Lerch, 1980: 133).

Despite the accuracy of Lewis's synthesis as a broad description of possessed individuals, it fails to be either unique, explanatory, or predictive. It does not require that the features which Lewis highlighted among cult mediums-jural impotence, low socio-economic status and high life frustration-be found only 
among cult mediums. Individuals with similar qualities can be identified who have avoided cultic affiliation. Dias's (1995) documentary history of the marginal women of nineteenth century São Paulo scarcely mentions any recourse to supernatural compensations.

Conversely, many are attracted to these religious forms despite failing to be, by Lewis's standard, demographically predisposed. Trance channels studied by Hughes are relevant counter-examples (Hughes, 1991: 179). Spiritualism in Victorian England was "most securely established amongst the ranks of respectable working- and middle-class people" (Owen, 1990: 8). Luhrmann judges the hypothesis that "the people join marginal groups out of socio-economic frustration" to be "patently false", at least when it comes to English magic groups (Luhrmann, 1989: 99). Magicians "are middle-class people of a particular, and not uncommon, temperamental cast-not people with similar socio-economic profiles" (Luhrmann, 1989: 100).

Even if everyone within the cult did fit Lewis's description, we would need to rule out the possibility that this involvement was epiphenomenal to some more generic reaction. Female preponderance within possession cults is hardly remarkable, since-in any situation where they are free to join at all-they outnumber men in almost every religious denomination (Batson \& Ventis, 1982: 36). It does not seem immediately warranted to assert special significance to their dominance here.

Lewis's portrait disappoints largely because of the ambiguity of his terms. For instance, where is the line separating the jurally impotent and the jurally potent? Ultimately, everyone is jurally impotent when compared to someone else, leading Pichler to note that "individuals in the upper classes can feel as marginalized as those of the lower classes" (Pichler, 1980: 111). Were jural impotence the cause of mediumship, everyone should become possessed. As this is not the case, apparently only certain levels or types of jural impotence-and of socio-economic status and life difficulty-render this effect. Unfortunately, we are not instructed as to what levels or types these might be. At best, "jural impotence" correlates with cult participation, but is not the unique cause Lewis posited. It is a characteristic of cult members, but without finer distinctions, it is also true of persons who are not members.

\section{Stress}

Lewis is right to focus on life difficulty or stress. Reports underscore its physical, cognitive and emotional consequences (e.g. Gross, 1970; Lazarus, 1986). Stress has been defined in various ways, but here, the idea refers to "a discrepancy between the demands impinging on a person ... and the individual's potential responses to these demands" (D. Mechanic, quoted by Gross, 1970: 55). This statement is a simple way to communicate Hans Selye's technical model:

Selye views stress as a state of the organism that underlies both its adaptive and maladaptive reactions. His paradigm of the stress response contains four main elements: antecedent stressor, defined as any agent that produces stress ... ; antecedent mediating factors that increase or decrease the impact of the stressor...; the adaptation syndrome, 
indicating an intervening state of stress in the organism ...; and consequent maladaptive responses. (Dohrenwend \& Dohrenwend, 1970: 114, emphasis in original)

Rephrased in these terms, Lewis proposes that stressors, such as political impotence and socio-economic deprivation, impinge on people who have few mediating factors to cope with these obstacles. Therefore, they respond (adapt) to this frustration by retreating into possession cults, either to renounce the external world and derive all major satisfactions from within this smaller circle (maladaptive response), or to accrue resources and skills which will permit eventual surmounting or negating of the obstructing stressor (adaptive response).

\section{A Critique of Lewis's Ecstatic Religion Model}

Shortcomings of the formulated model are mentioned above, notably the ambiguity of critical terms and the failure of the model to uniquely characterize its subjects. Beyond these, two internal assumptions, if incorrect, could warp the direction taken by the model's inferences.

Lewis implies firstly that quality-of-life judgments can be made about a specifiable sub-set of the population, based on socio-economic criteria, and secondly, that-given high life-stresses-that subset has nowhere else to turn than toward possession trance cults.

An event or condition is perceived as stress, particularly as negative stress, relative to that person's expectations:

An event that is intolerable and traumatic to one person might be difficult but manageable to another and hardly worth mentioning to a third. The degree of trauma produced by any given event is always and only determinable in relation to the degree to which it is self-dystonic, and the latter is determinable only in relation to the individual's psychobiographic past. However harsh it might seem, nothing is universally traumatic. (Wengle, 1988: 156)

Therefore, the socio-economic deprivations highlighted by Lewis cannot be presumed to be necessarily "stressful" for all who endure them (cf. Perlman, 1976: 182; Silverstein \& Krate, 1975: 6-7). Daniel Halperin makes the same point about Brazilians: despite "overwhelming political-economic exigencies", many still appear to enjoy a high quality of life (Halperin, 1996: 4).

Since it is not economic deprivation or social confinement which result in stress, we must look elsewhere. Finding no difference between mediums and non-mediums on a range of objective variables, Shapiro concludes that "it is the reaction to difficulty [and not difficulties themselves] that seems to distinguish the new medium from the control" (Shapiro, 1989: 14). Similarly, religious converts could not be distinguished from non-converts on an itemized inventory of stressful life events, but only on measures of perceived stress (Zinnbauer \& Pargament, 1998).

Stress exists only where it is perceived to exist by the experiencing person and not by the outside observer. Overriding any objective set of facts is the personal "subjective appraisal of the situation" (Lazarus, 1970: 145). "There is", Beck concludes, "considerable clinical evidence that stressful life situations, per se, are less important in the production of anxiety and physical disorders than the way 
in which these situations are perceived by individuals" (Beck, 1972: 349). Psychological stress is less of a thing than a process in which particular elements are assigned a distressful relationship (cf. Lazarus, 1986: 5-6; Ramos de Farias, 1985: 103).

The ambiguity which this fact creates for Lewis's model can be easily illustrated. He suggests that low socio-economic status correlates positively with participation in possession cults, because that status is indicative of powerlessness and high life-stress. However, the valuation of a socio-economic status depends on the standard for comparison. For instance,

the frame of reference for many Negro Americans has shifted during the past few decades. While formerly most Negroes judged how well off they were by their own previous conditions, the rising expectations of the present are increasingly framed in terms of the wider society. (Pettigrew, 1964: 187)

The same status, in other words, can be interpreted as stress-relieving-because it improves on an earlier status-or stress-inducing-because "the contrast between their relative poverty and the wealth elsewhere automatically makes them deprived" (Bohannan \& Curtin, 1988: 16). Consequently, "People in the same structural position may opt for different religions" (Mariz, 1994: 154) depending on how they perceive their life situations.

The sociological hypothesis that mediumship is tied to social and economic deprivations is thus tantamount to an implicit hypothesis about psychological perceptions. The core of Lewis's claim is that mediums are likely to be those dissatisfied with their socio-economic status whatever it happens to be (objectively), high or low. Mariz therefore concludes that "no specific element or situation helps characterize Afro-Brazilian Spiritists as distinct from Brazilians belonging to other religions. What distinguishes the Afro-Spiritists are their subjective experiences." (Mariz, 1994: 53)

Economic and jural variables are no longer immediate causes of cult affiliation, but feed into a third dimension which is not sociological, but psychological. This refinement generates expectations of participation patterns which are different from Lewis's original model.

In fact, in later writings Lewis does adopt a roughly analogous stance to that being suggested:

[Our] synchronic treatment of this comparative data indicates that, in different cultural and socioeconomic contexts, different classes of women are most at risk. In Ethiopia ... in traditional rural circles zar affliction seems to be particularly likely to affect the wives of men who abuse their traditional authority over women ...

In Tunisia, ... possession also seems to thrive in petty bourgeois society-being implicated in conflict between traditional and modern values and aspirations. In Egypt, in urban settings, possession is reported to thrive in more impoverished circumstances... In the Egyptian countryside, peasant cultivators are notably less likely to become chronic victims of possession than the wives of more secluded, betteroff, bourgeois merchants and the like. In Kuwait, perhaps the most striking case of all, those most at risk are alienated middle-class women, lacking the experience and education to participate in the lives 
of their husbands and children and, in other ways also, trapped in their luxurious new houses where they do not feel at home. (Lewis, 1991: 9-10)

Reflecting on this wide-ranging survey, Lewis concludes that "the common factor linked with possession seems to be the experience of identity-threatening stress, exacerbated by conditions of confinement and exclusion" (Lewis, 1991: 10).

Clearly, the model which Lewis suggests in Ecstatic Religion is not precisely the one he envisions 20 years later, although the genetic relationship between the two is plain to see. To distinguish the version of Lewis's model, the past tense is used when referring to his former position.

That Lewis no longer strictly argues the earlier version does not render its examination bootless-for two reasons: firstly, it has assumed a healthy life independent of Lewis. As described above, scholars constantly refer to Ecstatic Religion when interpreting their own data. As such, the question of how adequate an explanatory model that text offers is still a live issue, even if Lewis himself has moved on. Secondly, Lewis appears to have arrived at his revised model largely from an appraisal of the available literature. That is, he has not seen these changes as necessitated by the implications of the model itself. His revision is inductive, not theoretical. The discussion in this paper fills this gap.

Further, the earlier Lewis also assumed that the poor are constrained to choose mediumship to solve their life problems. If in fact they have other possible solutions, the sociological model is incomplete.

While the model identifies the source of stress, it does not explain why cult activity should be the inevitable solution. David Hess (1990) offers one possibility which is drawn from the victim's desire for vengeance with impunity. That is, a particular type of solution is sought, but not merely which could dispel the stress (e.g. 'I don't just want my boss to quit blocking my success, I want him to suffer for having opposed me').

However, we should inquire whether any organized alternatives exist. Washington suggests that whites turn to possession cults less frequently than blacks, because they "have access to such outlets as labor unions" (Washington, 1973: 119). Within the Brazilian milieu, functional equivalents also abound. Roberto DaMatta speaks of Carnival organizations and soccer clubs as having much in common with spiritist cults: they "unite the low and the weak with their magical and mystical powers" (DaMatta, 1991: 135). The availability of alternatives blunts the inevitability which Lewis tried to build into his model. We need to know more in order to explain why mediumship is the chosen route to stress reduction.

These criticisms show that Lewis's original thesis is likely to be incomplete. For a firmer conclusion, we should put him to the test. If this model is accurate as it stands, quantified measures of cultic participation should relate to measures of stress in a meaningful way.

Our investigation proceeds from two perspectives, the diachronic and the synchronic. The first compares Brazilian national census data regarding religious participation with demographic, social, health, and economic indices. Questionnaires completed by Brazilian respondents on a variety of religious, economic, and political topics provide the basis for the synchronic analysis. 


\section{Diachronic Analyses}

Method

This section compares changes in possession cult membership to other relevant statistics. The goal is to ascertain whether the relationships are those predicted by Lewis's model as described in Ecstatic Religion.

Annual national religious figures were gathered from the Anuário Estatístico do Brasil for the years 1947-1980. Possession trance cults are collectively listed under the term 'Espírita' and compared with data from Catholics and Protestants. These raw data were converted into rates of change which provide the baseline of comparison with measures of social stress.

Two limitations of the data should be noted. Firstly, not all relevant religious forms fall within the 'Espírita' census classification. The principal ones to mention here would be the Pentecostalists, who-like Umbanda and Candomblé-depend on the physical manifestation of spirits; Catholic charismatics might also belong more appropriately with the 'Espíritas'. This sorting error will minimize any differences between the groups.

A second limitation is the conflation of 'mediums' and 'members'. In the African cults, on which Lewis based his model, every member was also a medium. This equation does not hold for Brazilian spirit possession religions, although it is unclear whether non-mediumistic association would satisfy his model (these persons should be contrasted with 'clients' who utilize the services of the cult without any long-term associations). Thus, many census 'Espírita' members are not mediums. The possibility exists that an unfavorable result would change, if the data could be restricted to cult mediums, as opposed to cult members. If true, however, this would imply that a theory different from Lewis's is needed to account for non-mediumistic affiliation with peripheral spirit possession cults.

The study relates rates of religious affiliation to eleven national indicators of social and health development beginning with 1965 from the World Bank's Social Indicators of Development (World Bank, 1991): Population, Urban Population as Percentage of Total, Population Growth Rate, Urban Population Growth Rate, Urban/Rural Growth Difference, Crude Birth Rate, Crude Death Rate, Infant Mortality Rate, GNP per Capita, Daily Calorie Supply per Capita, and Daily Protein Supply per Capita. Economic measures include the general price index from the Estatísticas Históricas do Brasil (Instituto Brasileiro de Geografía Estatística, 1987). Finally, civic order was plumbed for Brazil by looking into numbers from its justice system taken from the Anuário Estatístico do Brasil (Instituto Brasileiro de Geografía Estatística, 1908-1989). All data collected for this analysis are available in Tables 8.1-8.6 of Donovan (1994).

The interest here is not the absolute value of any measure, but rather its rate of change as compared to the rates of change of religious affiliation. In simple terms, Lewis's model leads us to expect that when measures of life stress increase, rates of participation within 'Espírita' cults should also increase, and vice-versa.

\section{Results}

Religious Affiliation

Self-identified members of the Protestant and 'Espírita' cults represent small 
proportions of the Brazilian population. Despite steady 'market shares' (Protestantism claims about $4 \%$ of the population and Espiritism about $2 \%$ ), both experienced dramatic pulsations in their membership. Most notably, 1956 was a peak year for membership gains, not to be matched until 1980. 1971 provided significant defections from both, but most dramatically from Espiritism. It is not possible to pursue the reasons why these years stand out. Still, it is hard not to note McDonough's observation that "Repression of a kind [under the military dictatorship] peaked around 1971" (McDonough, 1981: xvii). Perhaps the steep drop in cult membership reflects the political oppressions of that year.

Precluding any assertion that these data are unreliable (the imperfections of Brazilian census data are widely acknowledged), any social indicator alleged to be the 'cause' of cultic membership should display similar spikes in an otherwise stable data line.

\section{Population Changes}

Crapanzano (1973: 126-127) depicts how urban/rural factors might prove relevant. However, fluctuations in religious affiliations cannot be attributed to broader population changes. All three measures-change rates for Population Growth Rate, Urban Growth Rate, and Urban-Rural Growth Differential-are stable.

This outcome contradicts Camargo's conclusion that "the greater the proportion of urban population, the greater the proportion of spiritists" (Camargo, 1973: 182). The urban growth rate has been very steady over the past 15 years, unlike the membership changes in 'Espírita' cults. Whatever the relationship between urbanism and possession cults, the latter are not a simple reflex of the former.

\section{Health and Nutrition Indicators}

Five indicators reflected health-related stress. Firstly, high infant mortality indicates low standards and stress-prone conditions, such as lack of medication, pre-natal care, and sanitary conditions. Especially helpful is Fleming-Moran's contention that infant mortality rates are "more sensitive to current health conditions" (Fleming-Moran, 1995: 153, emphasis added). This means that the infant mortality rate for a given year reflects conditions of that same year.

The steady decline in infant mortality (from 103.6 per 1,000 live births in 1965, to 74.2 in 1980) is not easily related to the volatile changes in cult affiliations. The same conclusion applies to similar declines in the crude death and birth rates.

While the daily calories-per-capita increased over this time, the daily protein supply was more variable. There does seem to be an inverse relationship between the second variable and percent changes in the 'Espírita' cults ( $r$ $=-.50$, while that for Protestantism is -.16 ). The possibility remains open that protein intake, or more likely the intermediate variables which influence protein intake (see below), does influence religious affiliation in the way Lewis described. 


\section{Economic Indices}

There are particularly high expectations that Brazilian economic indicators will be good predictors of possession activity. As shown by Baer (1989) and Alves (1985), they have a direct impact on the stress of everyday living (cf. Crapanzano, 1973: 85; Kluckhohn, 1944: 83-84). The GNP-per-capita data do correlate with rates of annual change in 'Espírita' membership at .36, and with membership in Protestantism at .67. This is, however, in the opposite direction from what Lewis would have predicted, since rising GNP-per-capita implies a lessening of economic stresses.

GNP-per-capita is probably too insensitive a measure, since wealth in Brazil is far from equitably distributed. Rate of change of the price index for all products [CPI] offers a better comparison. From 1973-1980, both religious memberships and CPI increased in tandem, as Lewis would have predicted. However, a big CPI leap occurred between 1958 and 1965, not falling off to original rates of change until about 1968. This period accounts for the greatest-and presumably most stressful-rates of change in consumer prices, peaking at $73.4 \%$. Yet, these years reveal no unusual migration toward either Protestant or 'Espírita' cults.

This analysis of national economic indicators fails to support expectations arising from Lewis's original model. Regional micro-analysis may yield more favorable results. For instance, considering data from Rio de Janeiro, a small, negative pattern which is reflected statistically $(r=-.12)$ does emerge between rates of change for the real minimum salary and changes in religious membership, in keeping with Lewis's prediction.

One explanation for the disappointing performance of economic data to track cult membership may be due to the years covered. While "Socio-economic analyses of present-day Brazil reveal intense rural and urban poverty, malnutrition, low income, marginality, and a poor quality of life", these facts co-exist with high occupational mobility and significant class permeability (Pastore, 1982: 160). Life might be bad now, but it was worse in the past, and this may result in an overall failure to perceive the economic situation as stressful. Perception, as argued earlier, is critical to the experience of stress.

Pastore's data for social and occupational mobility extend over 80 years ending in 1975, and the religious census data ends in 1980. Neither set of data takes into account the more recent economic turmoil within Brazil, and thus both may be typical of a more optimistic outlook than currently prevails. During recent decades, the economic outlook may have become more pessimistic, resulting in greater perceived stresses, in turn perhaps motivating higher cultic participation. Yet even this scenario would require refinement of Lewis's model, since it only serves to explain cult mediumship in times of adversity, but not during times of comfort. That is, people apparently do not leave the cult when conditions improve, and in good times they join for reasons wholly other than those considered by Lewis.

\section{Social Measures}

No completely satisfactory quality-of-life statistic could be identified; the best available pertains to penal populations. How many individuals per year were imprisoned, and of these, how many were imprisoned for homicides? Sharp 
increases in either of these data, but especially of the latter, could arguably be taken to indicate social disorder and chaotic tendencies which lower the quality of living and add to the stress of daily living (cf. Rangel, 1980; Pettigrew, 1964: $145,154)$ and should in turn correlate positively with cultic activity.

Homicide rates changed inversely to Protestant activity, generating a correlation of -.99 . However, the run of these data is only available for five years, so this result should not be over-emphasized. The better data for total imprisonments yield no discernible pattern either visually or statistically.

\section{Synchronic Analyses}

The diachronic national analyses yielded poor support for Lewis's model. To address the shortcomings, more nuanced data were collected from religious practitioners.

\section{Method}

\section{Subjects}

As part of a study of religious life in Rio de Janeiro in 1990 involving participant observation, 62 Brazilians completed a battery of questionnaires. 13 of these people were drawn randomly from the local telephone directory, diversifying the 49 solicited from friendship networks. Respondents from both sources were pooled into a single sample: Males: $N=36$, Age Range $=19-76$ years, Avg. Age $=35$ years; Females: $N=26$, Age Range $=23-64$ years, Avg. Age $=38$ years.

\section{Instruments}

Respondents completed a questionnaire assessing variables highlighted by Lewis as related to affiliation with peripheral possession trance cults. Firstly, a measure of socio-economic level, the "sócio-econômico-cultural" scale (SES), specifically designed for use in Brazil (Soares \& Fernandes, 1989), permitted the examination of the assertion that membership in spiritist cults is restricted to the lower classes (e.g. Camargo, 1973: 18).

Among the questions asked were two relating to perceptions of personal stress. The first sought to quantify stress: "I think that my life is Stressful/Balanced." The second tapped into the phenomenology of stress for that person: "I think that the majority of life's stresses are Motivating/Frustrating." The individual indicated on a seven-point scale where, between two polar contrasts, $\mathrm{s} / \mathrm{he}$ fell. Both items were scored so that higher levels indicated the more undesirable condition.

Finally, several items gauged the respondent's views on women in Brazilian society and were dichotomously (i.e. yes/no) scored. Higher scores indicate belief in female social and domestic potency. The object was to ascertain whether women, especially women in 'Espírita' cults, viewed themselves as repressed, oppressed, or otherwise marginalized. 


\section{Results}

\section{Socioeconomic Status}

Overall scores on the SES weakly correlated with religious participation $(r=.25)$ in a manner suggesting a small tendency for those not involved or weakly involved with these groups to enjoy higher socio-economic standing.

Subjects were sorted into three groups: those who had sole or primary membership in 'Espírita' cults (Primary Espíritas, $\mathrm{N}=29$ ); those who had secondary or tangential associations, i.e. were more likely to be regular clients than members of a cult (Secondary Espíritas, $\mathrm{N}=11$ ); and those who acknowledged no such ties (Non-Espíritas, $\mathrm{N}=22$ ). Group comparisons were made by analysis of variance, or ANOVA, a statistical method to test hypotheses about population means. The results revealed a non-significant $(\mathrm{F}=2.02, p=.14)$ trend, but in Lewis's predicted direction: Primary Espírita members had lower SES scores than Non-Espíritas, with Secondary Espíritas falling between the two. Religious affiliation may be typified by the socio-economic status of their members (cf. Maranell, 1974).

\section{Stress}

No relationship can be identified between cult membership and the amount of stress in a person's life. These variables correlated a meager .04, and when stress measures were sorted into membership categories and compared via ANOVA, no significant results obtained $(\mathrm{F}=0.81, p=.45)$.

On the other hand, those with Espírita involvement of any degree did tend to see stresses as being more frustrating than those without such involvements. The difference, however, was non-significant $(\mathrm{F}=0.93, p=.40)$. Life stress does not appear to be a powerful predictor of cult involvement, although hints of the trends which Lewis predicted are discernible.

\section{Women's Political Marginality}

According to Lewis, women are prone to participate in possession trance cults, because they lack jural authority to assert their demands through the political channels open to men. One solution to this obstacle is for the woman to act ostensibly as a surrogate for a socially acceptable authority, such as a male spirit. Within eighteenth-century Protestant Pentecostalism, women were allowed to preach only if they were in a trance, since the agency of the message could thereby be attributed to God and not to the otherwise presumptuous female (Garrett, 1987: 21, 45).

Fanny Tabak (1982: 129-130; 1983) agrees that the formal lines of Brazilian power and decision-making under-represent women, even when by some measures, especially economic and educational ones (d'Avila Neto, 1980: 14), they have made substantial progress. To the extent to which there is a 'female perspective' to be presented, it would seem that it is not being well attended to in the Brazilian political system.

Some of the lack of representation must be attributed to women's own disinterest: in Recife, $63.3 \%$ of women surveyed disavowed any political interests at all, $81.1 \%$ agreeing with the statement that "Politics is so complicated that 


\begin{tabular}{|c|c|c|c|c|}
\hline Hypothesis & Subject Groups & Mean & $S D$ & $\begin{array}{l}\text { ANOVA } \\
\text { Result }\end{array}$ \\
\hline $\begin{array}{l}\text { 1. Cult membership is a } \\
\text { function of socio-economic } \\
\text { status }\end{array}$ & $\begin{array}{l}\text { Primary } \\
\text { Espírita } \\
\quad(\mathrm{N}=29) \\
\text { Second. } \\
\text { Espírita } \\
\quad(\mathrm{N}=11) \\
\text { Non-Espírita } \\
(\mathrm{N}=22)\end{array}$ & $\begin{array}{l}41.38 \\
43.18\end{array}$ & 7.91 & $\begin{array}{c}\mathrm{F}=2.02 \\
p=.14\end{array}$ \\
\hline $\begin{array}{l}\text { 2. Cult membership is a } \\
\text { function of quantity of life } \\
\text { stress }\end{array}$ & $\begin{array}{l}\text { Primary } \\
\text { Espírita } \\
\text { Second. } \\
\text { Espírita } \\
\text { Non-Espírita }\end{array}$ & $\begin{array}{l}2.79 \\
3.73 \\
2.91\end{array}$ & $\begin{array}{l}2.08 \\
2.00 \\
2.22\end{array}$ & $\begin{array}{l}\mathrm{F}=0.81 \\
p=.45\end{array}$ \\
\hline $\begin{array}{l}\text { 3. Cult membership is a } \\
\text { function of perceiving stress } \\
\text { as frustrating }\end{array}$ & $\begin{array}{l}\text { Primary } \\
\text { Espírita } \\
\text { Second. } \\
\text { Espírita } \\
\text { Non-Espírita }\end{array}$ & $\begin{array}{l}5.00 \\
5.09 \\
4.23\end{array}$ & $\begin{array}{l}2.21 \\
2.17 \\
2.20\end{array}$ & $\begin{aligned} \mathrm{F} & =0.93 \\
p & =.40\end{aligned}$ \\
\hline $\begin{array}{l}\text { 4. Does not view women as } \\
\text { fundamentally different from } \\
\text { men }\end{array}$ & $\begin{array}{l}\text { Primary } \\
\text { Espírita } \\
\text { Second. } \\
\text { Espírita } \\
\text { Non-Espírita }\end{array}$ & $\begin{array}{l}0.66 \\
0.40 \\
0.50\end{array}$ & $\begin{array}{l}0.48 \\
0.52 \\
0.51\end{array}$ & $\begin{array}{l}\mathrm{F}=1.20 \\
p=.31\end{array}$ \\
\hline $\begin{array}{l}\text { 5. Does not believe men are } \\
\text { significantly more privileged } \\
\text { than women }\end{array}$ & $\begin{array}{l}\text { Primary } \\
\text { Espírita } \\
\text { Second. } \\
\text { Espírita } \\
\text { Non-Espírita }\end{array}$ & $\begin{array}{l}0.18 \\
0.30 \\
0.14\end{array}$ & $\begin{array}{l}0.39 \\
0.48 \\
0.35\end{array}$ & $\begin{array}{l}\mathrm{F}=0.60 \\
p=.55\end{array}$ \\
\hline $\begin{array}{l}\text { 6. Feels able to make decisions } \\
\text { for him/herself }\end{array}$ & $\begin{array}{l}\text { Primary } \\
\text { Espírita } \\
\text { Second. } \\
\text { Espírita } \\
\text { Non-Espírita }\end{array}$ & $\begin{array}{l}3.55 \\
4.55 \\
4.00\end{array}$ & $\begin{array}{l}2.54 \\
2.58 \\
2.62\end{array}$ & $\begin{aligned} \mathrm{F} & =0.63 \\
p & =.54\end{aligned}$ \\
\hline $\begin{array}{l}\text { 7. Feels on equal footing with } \\
\text { opposite sex }\end{array}$ & $\begin{array}{l}\text { Primary } \\
\text { Espírita } \\
\text { Second. } \\
\text { Espírita } \\
\text { Non-Espírita }\end{array}$ & $\begin{array}{l}5.69 \\
5.64 \\
5.32\end{array}$ & $\begin{array}{l}1.61 \\
1.69 \\
1.91\end{array}$ & $\begin{array}{c}\mathrm{F}=0.30 \\
p=.74\end{array}$ \\
\hline
\end{tabular}

Summary Results for Synchronic Analyses.

often we can't follow what happens". Comparable figures for men are $53.7 \%$ and 72.0\%, respectively (Sá, 1985: 14-15; cf. Patai, 1988: 181). This lack of interest does not arise from low self-esteem among women, since $73 \%$ of them believe that a female "é capaz de exercer o cargo de Prefeito do Recife" (is able to perform the duties of the mayor of Recife) as well as, or better than, a male (Sá, 1985: 25; cf. Burdick, 1993: 111). This accords well with the present sample: virtually every respondent expressed willingness to vote for a woman President of Brazil.

Sá concludes this revealing study by characterizing the typical female respondent: 
They have little or no political interest. They agree that politics is a complicated subject, and from this bias they do not participate during political campaigns. They don't cooperate financially; they don't go to assembly meetings, and only get their information about candidates from radio and television programs during elections because these don't require involvement. (Sá, 1985: 31)

This portrait does not contradict that of the present sample. Women were lukewarm about the statement, "Do you believe that you have the same opportunities in the business world as a man with the same qualifications?" (Mean $=0.6, S D=0.5$ ). There was only a slight tendency to answer affirmatively. A slightly negative response was obtained to a second question, "Have you ever felt inferior or belittled simply for being a woman?" (Mean $=0.62, S D=0.5$ ).

Closer analysis reveals that those most likely to have experienced belittlement are Secondary Espíritas, while those least likely are Non-Espíritas. Primary Espíritas fell between the other two groups. The differences were not significant.

Males in the sample do not seem to indulge a radically different view of sex relations. Responding to similar questions from their own perspective ("Do you believe that women have the same opportunities in the business world as a man with the same qualifications?" and "Are there situations that do not depend solely upon physical strength where you expect a worse performance from a woman than from a man?"), the men generated a similar pattern of weak affirmation and denial, respectively (Mean $=0.63, S D=0.49 ; \quad$ Mean $=0.70$, $S D=0.47)$.

The sample seems evenly split on the question, "Beyond the obvious physical differences, do you believe that men and women are fundamentally different?" Primary Espíritas were more likely to deny such fundamental sex differences than were Secondary Espíritas. Non-Espíritas fell between the two extremes, although again the differences were not significant $(\mathrm{F}=1.20, p=.31)$. Few respondents disagreed with the statement that "In Brazil, men have more privileges than women", while only one agreed that "men ought to have more privileges".

Intergroup contrasts are little clarified by shifting the focus from the public arena to the private. All groups aggregated around the neutral pole when recording their level of agreement (from 1 to 7 ) to the statement, "Personal and domestic decisions are made by me, and don't need the approval of other people". Comparing response patterns by sex did not improve this outcome. Only slightly more forceful was their agreement to the claim that "In a discussion, I am on equal footing with an opponent of the opposite sex".

All things considered, the perceived position of women seems somewhat lower than that of men. Everyone is aware of the situation and few condone it. Still, the consensus of this sample was that few women felt seriously impeded by their sex and men not overly concerned to impede them. This result matches that arrived at by d'Avila Neto (1980) who found that while women faced what might be termed traditional conservative constraints, it was the women themselves, and not the men, who felt it important to maintain such social constraints. Degree of involvement within possession cults does not significantly alter this general picture.

The synchronic analysis does offer better support for Lewis than did the national census data. The inability to reach significance may be due to the small 
sample, but this failure is not the major problem for Lewis's model. More respondents might improve the levels of significance $(p)$, but not necessarily the degrees of correlation $(r)$. The relationships between religious affiliation and the other variables were weak, too weak to account fully for the phenomenon, even had they been significant. The general accuracy of Lewis's model was conceded at the outset; my objective has been to demonstrate the need to supplement this model-the present data are adequate to press that point.

\section{Conclusions}

Although impressive ethnographic studies support Lewis's claim that spirit mediumship relates to such socio-political variables as jural impotence and social marginality, numerous accounts to the contrary also exist. Shapiro (1990) examined a Brazilian group of first-time mediums and concluded that they "cannot be characterized as disenfranchised", finding no "support [for] the notion that illness, misfortune or jural impotence is causally related to the onset of spirit possession" (Shapiro, 1989: 14). Researching women living within a Recife favela (slum), Fátima Quintas (1986: 74) found that of 582 persons surveyed, $81 \%$ considered themselves Catholic and only one person claimed spiritist activity. Only $4 \%$ of favelados randomly surveyed by Janice Perlman (1976: 59) in Rio de Janeiro were Spiritists. Significantly, the élite, as opposed to the expected 'disenfranchised' of this population, reported $11 \%$.

It would be difficult to imagine a more graphic depiction of impotent, desperate life circumstances than that by Nancy Scheper-Hughes (1992) in Death without Weeping. While her focus is on the pitiful deaths of children from chronic malnutrition, she contextualizes her discussion by elaborating the heavy burdens of life of the underclass in the Brazilian Nordeste. If Lewis is correct, this setting should provide fertile ground for possession trance activity. While such cults are available for selection, Scheper-Hughes reports that $85 \%$ describe themselves as Catholic (Scheper-Hughes, 1992: 330), a figure not very different from the $88 \%$ reported in the 1960 census for the much better-off in Rio de Janeiro (IBGE, 1968a: 6). What makes this census interesting is its simultaneous count of the favelas in the heart of the city-state. There, over $91 \%$ claimed Catholicism as their religion (IBGE, 1968b: 4). In other words, there was greater professed Catholic affiliation in the poorest conditions of the city, precisely where Lewis might have predicted a migration toward alternative, compensatory peripheral 'Espírita' cults.

The empirical studies reported here demonstrate that the variables identified by Lewis are not irrelevant to the focal phenomena, but only that they fall short of being fully explanatory. The model, in other words, clearly requires improvement, but not discarding.

As discussed earlier, later writings by Lewis do refine the sociological dimensions of this thesis: they suggest that socio-economic and jural variables are important only to the extent to which they generate not merely stress, but 'identity-threatening' stress. Interestingly, Lewis enlists a psychological variable to unify the sociological ones he favored earlier. Mediumship is now to be understood as a reaction to a personal interpretation of the individual's social situation. Lewis arrived at this revision through generalizing inductively across specific ethnographic accounts. My discussion concludes that his intuitive conclusions are justified both theoretically and empirically. 
While the revised model can be expected to serve better as explanation and predictor than did the model offered in Ecstatic Religion, it remains to be seen whether it can perform these tasks without the need for further supplementation. An additional, more fundamental explanatory variable may be one Lewis excluded through his initial opposition between the social and the arbitrary: the psycho-biological.

Space precludes elaboration, but the following facts would be relevant to any such argument: possession trance is a cultural, but not an individual universal. Not all persons, even in supportive contexts, are able to achieve this altered state. The first cut between mediums and non-mediums is probably not along sociological lines, but according to genetic and developmental criteria which make entry into trance possible (Donovan, 1994; McClenon, 1997). While Lewis's early model fares poorly when predicting mediumship from among all persons, it should perform better when applied only to those persons constitutionally able to enter into the possession trance.

James M. Donovan is currently on leave from his position at the Tulane Law Library. Fieldwork for his doctorate in anthropology was conducted in 1990 among Candomble participants in Rio de Janeiro, Brazil. Related publications have appeared in Method \& Theory in the Study of Religion, Seton Hall Constitutional Law Journal, and the Yearbook of Cross-Cultural Medicine and Psychotherapy. Correspondence: $\mathrm{Tu}$ lane Law Library, Tulane University, 6329 Freret, New Orleans, LA 70118-6231, USA.

\section{REFERENCES}

Alves, M. H. M. State and Opposition in Military Brazil. Austin, Texas: University of Texas Press, 1985. Baer, W. The Brazilian Economy: Growth and Development. New York: Praeger, 1989 (3rd ed.).

Batson, C. D. \& Ventis, W. L. The Religious Experience: A Social-Psychological Perspective. New York: Oxford University Press, 1982.

Beck, A. T. "Cognition, Anxiety, and Psychophysiological Disorders." In Spielberger, C. D., ed. Anxiety: Current Trends in Theory and Research. Vol. II. New York: Academic Press, 1972: 343-354.

Bilu, Y. \& Goodman, Y. C. "What Does the Soul Say? Metaphysical Uses of Facilitated Communication in the Jewish Ultraorthodox Community." Ethos 25 (4), 1997: 375-407.

Bohannan, P. \& Curtin, P. Africa and Africans. Prospect Heights: Waveland Press, 1988 (3rd ed.).

Bourguignon, E. Possession. Prospect Heights: Waveland Press, 1991.

Burdick, J. Looking for God in Brazil: The Progressive Catholic Church in Urban Brazil's Religious Arena. Berkeley: University of California Press, 1993.

Camargo, C. P. Católicos, Protestantes, Espíritas. Petrópolis: Editora Vozes, 1973.

Crapanzano, V. The Hamadsha: A Study in Moroccan Ethnopsychiatry. Berkeley: University of California Press, 1973.

DaMatta, R. Carnivals, Rogues, and Heroes: An Interpretation of the Brazilian Dilemma. Translated by John Drury. Notre Dame: University of Notre Dame Press, 1991.

d'Avila Neto, M. I. O Autoritarismo e a Mulher. Rio de Janeiro: Achiamé, 1980.

Dias, M. O. S. Power \& Everyday Life: The Lives of Working Women in Nineteenth-Century Brazil. Translated by Ann Frost. New Brunswick: Rutgers University Press, 1995.

Dohrenwend, B. S. \& Dohrenwend, B. P. "Class and Race as Status-Related Sources of Stress." In Levine, S. \& Scotch, N. A., eds. Social Stress. Chicago: Aldine Press, 1970: 111-140.

Donovan, J. M. Defining "Religion": Death and Anxiety in an Afro-Brazilian Cult. Ph.D. Dissertation, Tulane University, 1994.

Fleming-Moran, M. "Health Status Indicators for Rural Societies in Transition: Estimating Morbidity and Mortality Using National and Community Data." In Moran, E. F., ed. The Comparative Analysis of Human Societies. Boulder: Lynne Rienner Press, 1995: 149-172.

Garrett, C. Spirit Possession and Popular Religion. Baltimore, MD: Johns Hopkins University Press, 1987. 
Gross, E. "Work, Organization and Stress." In Levine, S. \& Scotch, N. A., eds. Social Stress. Chicago: Aldine Press, 1970: 54-110.

Halperin, D. "From Guilt to Gaya Scienza." Anthropology Newsletter 37 (2), 1996: 4.

Hess, D. J. "Ghosts and Domestic Politics in Brazil: Some Parallels between Spirit Possession and Spirit Infestation." Ethos 18 (4), 1990: 407-438.

Hughes, D. J. "Blending with an Other: An Analysis of Trance Channeling in the United States." Ethos 19 (2), 1991: 161-184.

Instituto Brasileiro de Geografía e Estatística (IBGE). Censo Demográfico de 1960, VII. Recenseamento Geral do Brasil, Série Regional, Volume I, Tomo XII, 2a Parte Guanabara. Rio de Janeiro, 1968a.

Instituto Brasileiro de Geografía e Estatística (IBGE). Censo Demográfico de 1960, VII. Recenseamento Geral do Brasil, Série Especial, Volume IV: Favelas do Estado do Guanabara. Rio de Janeiro, 1968b.

Instituto Brasileiro de Geografía Estatística (IBGE). Estatisticas Historicas do Brasil. Rio de Janeiro: Secretaria de Planejamento e Coordinação da Presidencia da Republica, Fundação IBGE, 1987.

Instituto Brasileiro de Geografía Estatística (IBGE). Anuário Estatístico do Brasil. Rio de Janeiro: Departmento de Divulgação Estatística, Fundação IBGE, 1908-1989.

Kluckhohn, C. Navaho Witchcraft. Boston: Beacon Press, 1944.

Lazarus, R. S. "Cognitive and Personality Factors Underlying Threat and Coping." In Levine, S. \& Scotch, N. A., eds. Social Stress. Chicago: Aldine Press, 1970: 143-164.

Lazarus, R. S. "Stress: Appraisal and Coping Capacities." In Eichler, A.; Silverman, M. M. \& Pratt, D. M., eds. How to Define and Research Stress. Washington, D. C.: American Psychiatric Press, 1986: 5-12.

Leão Teixeira, M. L. “Transas de um Povo de Santo: Um Estudo sobre Identidade Sexuais.” Master's Thesis, Universidade Federal do Rio de Janeiro, 1986.

Lerch, P. "Spirit Mediums in Umbanda Evangelizada of Porto Alegre, Brazil: Dimensions of Power and Authority." In Bourguignon, E., ed. A World of Women. New York: Praeger Press, 1980: 129-159.

Lerch, P. "An Explanation for the Predominance of Women in the Umbanda Cults of Pôrto Alegre, Brazil." Urban Anthropology 11 (2), 1982: 237-261.

Lewis, I. M. Ecstatic Religion: A Study of Shamanism and Spirit Possession. London: Routledge, 1989 (2nd ed.; 1st published in 1971).

Lewis, I. M. Religion in Context: Cults and Charisma. Cambridge: Cambridge University Press, 1986.

Lewis, I. M. "Introduction: Zar in Context: The Past, the Present and the Future of an African Healing Cult." In Lewis, I. M.; Al-Safi, A. \& Hurreiz, S., eds. Women's Medicine: The Zar-Bori Cult in Africa and Beyond. Edinburgh: Edinburgh U.P., 1991: 1-16.

Luhrmann, T. M. Persuasions of the Witch's Craft: Ritual Magic in Contemporary England. Cambridge: Harvard University Press, 1989.

Maranell, G. M. Responses to Religion: Studies in the Social Psychology of Religious Belief. Lawrence: University Press of Kansas, 1974.

Mariz, C. L. Coping with Poverty: Pentecostals and Christian Base Communities in Brazil. Philadelphia: Temple University Press, 1994.

McClenon, J. "Shamanic Healing, Human Evolution, and the Origin of Religion." Journal for the Scientific Study of Religion 36 (3), 1997: 345-354.

McDonough, P. Power and Ideology in Brazil. Princeton: Princeton University Press, 1981.

Mischel, W. \& Mischel, F. "Psychological Aspects of Spirit Possession." American Anthropologist 60 (2), 1958: 249-260.

Owen, A. The Darkened Room: Women, Power and Spiritualism in Late Victorian England. Philadelphia: University of Pennsylvania Press, 1990.

Pastore, J. Inequality and Social Mobility in Brazil. Translated by R. M. Oxley. Madison: University of Wisconsin Press, 1982.

Patai, D. Brazilian Women Speak: Contemporary Life Stories. New Brunswick: Rutgers University Press, 1988.

Pereira de Queiroz, M. I. "Afro-Brazilian Cults and Religious Change in Brazil." In Beckford, J. A. \& T. Luckmann, eds. The Changing Face of Brazil. London: Sage, 1989: 88-108.

Perlman, J. E. The Myth of Marginality: Urban Poverty and Politics in Rio de Janeiro. Berkeley: University of California Press, 1976.

Pettigrew, T. F. A Profile of the Negro American. Princeton: D. van Nostrand, 1964.

Pichler, W. A. "Algumas Observações sobre o Conceito de Marginalidade Social." Ensaios FEE 1 (1), 1980: 109-122. 
Quintas, F. Sexo e Marginalidade: Um Estudo sobre a Sexualidade Feminina em Camadas de Baixa Renda. Petrópolis: Editora Vozes, 1986.

Ramos de Farias, F. "Sobre o Conceito de Estresse." Arquivos Brasileiros da Psicologia 38 (4), 1985: 97-105.

Rangel, I. “Criminalidade e Crise Económica." Ensaios FEE 1 (1), 1980: 95-107.

Rouget, G. Music and Trance: A Theory of the Relations between Music and Possession. Translated by Brunhilde Biebuyck. Chicago: University of Chicago Press, 1985.

Sá, C. P. A Participação Política da Mulher no Recife: Eleições de 1982. Recife: Fundação Joaquim Nabuco, Instituto de Pesquisas Sociais, 1985.

Scheper-Hughes, N. Death without Weeping: The Violence of Everyday Life in Brazil. Berkeley: University of California Press, 1992.

Shapiro, D. J. "Healing as Explanation: A Case Control Study of First Entry into Possession Trance." Paper presented to the 88th Annual Meeting of the American Anthropological Association, Washington, D. C., 1989.

Shapiro, D. J. "Ontology of Possession-Trance in Selected Brazilian Settings." Paper presented to the 89th Annual Meeting of the American Anthropological Association, New Orleans, 1990.

Silverstein, B. \& Krate, R. Children of the Dark Ghetto: A Developmental Psychology. New York: Praeger Press, 1975.

Soares, N. E. \& Fernandes, L. M. "A Medida do Nível Sócio-Econômico-Cultural." Arquivos Brasileiros de Psicologia 41 (2), 1989: 35-43.

Tabak, F. "O Papel da Mulher na Definição das Políticas Públicas no Brasil." Revista Brasileira de Estudos Políticos 54, 1982: 107-132.

Tabak, F. Autoritarismo e Participação Política da Mulher. Rio de Janeiro: Edições Graal, 1983.

Washington, J. R. Black Sects and Cults. Garden City: Anchor Press, 1973.

Wengle, J. L. Ethnographers in the Field. Tuscaloosa: University of Alabama Press, 1988.

World Bank. Social Indicators of Development 1990. Data on diskette $\left(2 \times 3.5^{\prime \prime}\right.$ diskettes). Washington, D.C.: World Bank, 1991.

Zinnbauer, B. J. \& Pargament, K. I. "Spiritual Conversion: A Study of Religious Change among College Students." Journal for the Scientific Study of Religion 37 (1), 1998: 161-179. 